\title{
As well as I can / As I best can / As best as I can - Some properties of potentiality equatives
}

\author{
Jarich Hoekstra \\ Christian-Albrechts-Universität Kiel
}

This article discusses a special type of equative comparison constructions: Potentiality equatives, i.e. equatives with a standard clause containing a predicate of physical or cognitive ability, or epistemic possibility. The focus in this article is on potentiality equatives involving a (negative) comparative or a superlative in the standard clause, as these seem to give a particularly clear insight into the properties of this construction type. It is argued that the broad syntactic variation in potentiality equatives is caused by their specific semantics, by their expressive force and by their idiomatic nature.

Keywords: Comparison, equative, potentiality, entailment, expressive force, idioms

\section{Introduction}

In this article I want to draw attention to a special type of equative comparison constructions in West Germanic languages that has hitherto gone practically unnoticed, namely potentiality equatives. ${ }^{1}$ Equative constructions in general have been discussed by Haspelmath \& Buchholz (1998) and Henkelmann (2006). From Haspelmath \& Buchholz I adopt the following terminology:

John is as tall as his brother (is)

comparee parameter marker parameter standard marker standard

The standard can be clausal or phrasal. A clause expressing the standard will be referred to as standard clause.

Potentiality equatives are defined here as clausal equatives with a standard clause containing a potentiality predicate, i.e. a predicate of physical or cognitive ability, or epistemic possibility (e.g. as well as I can). Potentiality equatives have two interesting constructional variants: 
i. Instead of having a positive in the parameter position (as in as well as I can), they may involve a (negative) comparative or a superlative in the standard clause (e.g. as I best can).

ii. They may show syntactically illegitimate 'fronting' of this comparative or superlative into the parameter position (e.g. as best as I can).

Both these variants are denotationally equivalent to the construction with the positive in the parameter position.

In Section 2 I will present some data from West Germanic languages exemplifying the first variant. In Section 3 I will try to account for the fact that a potentiality equative with a (negative) comparative or a superlative in the standard clause can be denotationally equivalent to a potentiality equative with a positive in the parameter position. In Section 4 I will present data exemplifying the second variant. In Section $5 \mathrm{I}$ will attempt to make sense of the fact that a comparative or a superlative may appear in the parameter position and, more generally, of the fact that the adjective/adverb in potentiality equatives may show up in non-canonical forms and positions. Section 6 contains the conclusion.

\section{Data I}

First, we will have a look at potentiality equatives containing a (negative) comparative or a superlative in the standard clause. Consider the following examples from Modern High German with a (negative) comparative in the standard clause: ${ }^{2}$

(1) a. Vanessa und Justine sind zwei Schwestern wie sie nicht Vanessa and Justine are two sisters as they not unterschiedlicher sein könnten.

more.unlike be could

'Vannessa and Justine are two sisters who could not be more unlike.' [http://www. vorablesen.de/buecher/im-zauber-der-sirenen/ rezensionen/verfuehrrerische-sirenen]

b. Jane und Roxy sind zwei Schwestern, wie sie Jane and Roxy are two sisters as they unterschiedlicher nicht sein könnten. more.unlike not be could 'Jane and Roxy are two sisters who could not be more unlike.' [http://www.sat1.de/film/ein-verrueckter-tag-in-new-york]

In this construction the comparative may either follow the negation (as in (1a)) or precede it (as in (1b)). In the latter case it can be assumed that the comparative has undergone scrambling over the negation (cf. Hoeksema 2003; Hoekstra 
to appear). The word order with scrambling seems to be the most frequent one in German. A Google search on 11 February 2014 yielded, for example, 308 hits for wie er schöner nicht sein kann against 60 hits for wie er nicht schöner sein kann. Here are some further examples with scrambling:

(2) a. Hier erwartet Sie ein Urlaub, wie er schöner nicht sein kann. Here awaits you a holiday, as he more.beautiful not be can 'Here awaits you a holiday that cannot be more beautiful.' [http://www.urlaub-anbieter.com/apart-hilde]

b. Zu guter Letzt folgt mit ’God Only Knows` eine to good last follows with , God Only Knows a melancholische Pianoballade wie sie trauriger nicht sein kann. melancholic pianoballad as she sadder not be can 'At last follows with `God only Knows` a melancholic piano ballad that could not be sadder.' [http://www.classicrockmag.de/review/raitt-bonnie]

Scrambling of a comparative over the negation is restricted to this particular construction in German. The predicate in the construction, normally sein können, denotes possibility. ${ }^{3}$

In Early Modern Dutch (until the 19th century) we find a fixed expression involving the comparative beter 'better' inside a standard clause with the verb weten 'to know', which denotes cognitive ability:

(3) a. ' $k$ Ken hier al d' adeldom, zo ik niet beter weet.

I know here all the noblemen, so I not better know

'I know all the noblemen here, as far as I know.'

[Pieter Langendyk, Het wederzyds Huwelyks bedrog (1720)]

b. Zoo ik niet beter weet is Broeder J H en zijn vrouw goed As I not better know is brother $\mathrm{J} \mathrm{H}$ and his wife good gezond en hij is heel spoedig een jonge zoon of dochter te verwagten. healthy and he is very soon a young son or daughter to expect 'As far as I know, brother $\mathrm{J} \mathrm{H}$ and his wife are in good health and he is expecting a young son or daughter very soon.'

[http://www. tesellefamily.com/ned_content/ned_brieven/brief_06 (letter of April 5, 1869)]

This construction is more or less equivalent to English expressions like as far as I know or to the best of my knowledge.

Similar examples are found in (Early) Modern West Frisian (cf. Hoekstra 2012):

(4) a. Wy ha zeis Bén han / fjouwer binne dae / twa libje iette / We have six children had / four are dead/two live still / 
Za ik better net wit: uis Griet / en uis mijn Heer! [1778o]

so I better not know: our Griet / and our Milord!

'We had six children, four are dead, two are still alive, as far as I

know: our Griet and our Milord.'

b. As ik net better wit, is hylyk mei elts-en-ien.

As I not better know, is he even with everyone

'As far as I know, he is even with everyone.'

[Rimen en Teltsje 211 (1994)]

In (4a) we find the scrambling of the comparative over the negation that we also observed in (1b) and (2) in German. Note that in both Early Modern Dutch and Early Modern Frisian the parameter marker $z o(o) / z a$ could sometimes be used instead of or with a deleted standard marker (also compare the older Dutch examples in (6) and (7)).

In English constructions occur in which the superlative best shows up inside a standard clause. The predicate is the modal verb can expressing physical or cognitive ability (sometimes accompanied by main verbs like tell, describe, recall etc.) or the verb know. This construction is found in older English, but also sometimes in modern sources:

(5) a. The flour is goon, ther is na-more to telle,

The bren, as I best can, now moste I selle.

[Geoffrey Chaucer, The Prologue to the Wife of Bath's Tale, 477-8]

'The flour is gone, there is no more to tell, / I must now sell the brans, as well as I can'

b. I have been studying lute technique as I best can from home, using books, the internet and some DVDs I have.

[http://www.mail-archive.com/lute@cs.dartmouth.edu/msg34595.html]

c. I'll tell it as I best know how, / And this is the way it was told me...

[songlines from: Joanna Newsom and the Ys Street Band, Colleen]

In Middle Dutch and Early Modern Dutch until the 19th century we find basically the same construction as in English (cf. Van der Horst 2008: 364, 587, 810, 1091-1092): ${ }^{4}$

(6) a. Doe viel sciere neder / Sente Brandaen op sine knien / Then fell quickly down Saint Brendan on his knees ende bat Gode dat hi moeste ontvlien / dien diere so hi best can. and prayed God that he might escape that animal so he best can 'Then St. Brendan fell quickly down on his knees and prayed to God that he might escape from that animal as well as he could.' [De reis van St. Brandaan, 12th century, r. 1022]. 
b. Wy bevonden het onder water noch dicht en wel, We found it under water still close and well en vermaekten het boven, zoo als wy in zee, onder het zeilen, and repaired it above, so as we in sea, under the sailing, best kosten.

best could

'We found, that under the water it was still close and well, and repaired it above, as well as we could, at sea, while sailing.' [Joan Nieuhoff, Zee en Lant-Reize door verscheide Gewesten van Oostindien 4 (1682)]

The superlative, normally (but not exclusively) best, is contained in the standard clause. The predicate is the modal verb connen or moghen in the sense of 'be able'. In the work of Jancko Douwama (16th century), a Frisian writing a Low Germancoloured Middle Dutch, the construction appears with the verb weten:

(7) Sijne Gnaden ginck met mi; om de wal 3 malen,

His Grace went with me around the rampart 3 times en fraegden mij voele dingen, daer ick vp antuorden so ick best wiste. and asked me many things, there I on answered so I best knew 'His Grace went with me around the rampart three times and asked me many things, which I answered as well as I could.'

[Jancko Douwama's geschriften I, 149 (1830)]

Summarizing, there seems to be a tendency in West Germanic languages in potentiality equatives to have a comparative or a superlative realized in the standard clause instead of a positive in the parameter position.

\section{Analysis I}

One property of the constructions that were introduced in the previous section seems to be that they are denotationally equivalent to equative constructions with a positive in the parameter position. Compare:

(8) wie sie unterschiedlicher nicht sein könnten $\leftrightarrow$

so unterschiedlich wie sie nur sein könnten

zo ik niet beter weet $\leftrightarrow \quad$ zo goed als ik weet

as ik better net wit $\leftrightarrow \quad$ sa goed as ik wit as I best can $\leftrightarrow \quad$ as well as I can

The predicate in all these constructions is a potentiality predicate; it denotes physical or cognitive ability, or epistemic possibility. Equatives with potentiality 
predicates give rise to (mutual) entailments like the following: If I do something as well as I can, I can't do it any better than that and I am doing it to the best of my ability. Similarly, if I tell something as well as I know, I don't know it any better than that and I am telling it to the best of my knowledge. And in the case of the German example: If two sisters are as unlike as they can possibly be, they cannot be more unlike than that and they are in fact, to put it in German, möglichst unterschiedlich. These strong mutual entailments do not appear with normal clausal equatives like The tower is as high as it was before the war. Although this sentence may entail Before the war the tower was not higher than it is now the reverse entailment does not hold (the tower may have been lower before the war). A superlative entailment is not available at all.

This raises the question of what is special about the semantics of potentiality equatives that distinguishes them from normal clausal equatives. Normal clausal equatives have an 'at least' interpretation, i.e. the value of its standard sets a lower bound on the measure of its comparee, but they may have an 'exactly' interpretation. A sentence like The tower is as high as it was before the war can mean that the tower is at least as high as it used to be (it may be higher), but it may also mean that the tower is exactly as high as it used to be. There is an ongoing discussion in the semantic literature about the question of what accounts for these interpretations (see Rett 2010, to appear, for an overview and a new proposal).

Potentiality equatives only have an 'exactly' reading, i.e. the value of the standard is identical to the measure of the comparee, and they express an absolute maximum. ${ }^{5}$ This means that the use of expressions like exactly in such equatives is tautological:

(9) He jumps ( ${ }^{*}$ exactly) as high as he can.

To get the 'exactly' interpretation, the subject of the standard clause must be coreferential with the main clause subject (as in (9)), or it must be a generic subject (He jumps as high as one possibly can) or an impersonal subject (He jumps as high as (it) is humanly possible). With a non-coreferential subject the 'at least' (and 'exactly') interpretation of normal equatives reappears and it becomes possible again to insert exactly:

(10) He jumps (exactly) as high as his sister can jump.

Potentiality equatives may contain the restrictive scalar particle maar/mar/nur in Dutch, Frisian and German (Foolen 1993), which strengthens the 'absolute maximum' interpretation. Compare: ${ }^{6}$

(11) a. Er läuft so schnell wie er (nur) kann.

b. Die Schwestern waren so unterschiedlich wie sie ${ }^{*}$ (nur) sein könnten. 'the sisters were as unlike as they could (possibly) be' 
The 'exactly' and 'absolute maximum' interpretation of potentiality equatives accounts for the mutual positive, (negative) comparative or superlative entailments these equatives give rise to. The semantics of potentiality equatives are the prerequisite for realizing the adjective/adverb in these constructions as a (negative) comparative or a superlative in the standard clause. The comparative and the superlative may be considered as overt instantiations of the covert degree phrase that is traditionally assumed to be present in comparison clauses (Bresnan 1973; Chomsky 1977; Kennedy 1999).

The question that remains is why there is variation at all. Why use a comparative or a superlative when you could just as well use a positive? Here it seems relevant that the constructions that we discussed in Section 2 are more expressive than their counterparts with a positive in the parameter position; whereas as well as I can can be neutral, as I best can explicitely emphasizes the 'absolute maximum' interpretation. Another thing to note is that all these constructions are more or less idiomatic, i.e. they are formulaic expressions with a restricted number of variables or they have become fully fixed. Before discussing the expressive force and the idiomatic nature of the constructions in some more detail in Section 5, I want to introduce a set of data that may illustrate these points even more clearly.

\section{Data II}

The cases that we discussed in Section 2 do not exhaust the variation that is possible in this type of constructions. In the German construction the comparative can also appear in the parameter position:

(12) Die drei Schwestern sind unterschiedlicher wie sie nicht sein könnten. The three sisters are more.unlike than they not be could. 'The three sisters are as unlike as they could be.' [http://www.rupprecht.de/Popup_buchempfehlung_archiv.php?empfid=95]

This variant is less accepted than the one in (1) and (2), but still quite common. A Google search on 11 February 2014 yielded, for example, 34 hits for schöner wie er nicht sein kann. Here are some further examples:

(13) a. Die Geschichte an sich klingt kitschiger, wie sie nicht sein kann. The story on itself sounds more.kitschy, as she not be can 'The story in itself sound as kitschy as it can be.'

[http://www. potzdam.de/05_juli/berlinale_2008.htm]

b. Der ganze Film ist hohler wie er nicht sein könnte

The whole film is more.mindless as he not be could 
und voller blutiger Gewalt.

and full.of bloody violence

'The whole film was as mindless as it could be and full of bloody violence.'

[http://www. lovefilm.de/film/Must-Love-Death/ 292761/ review]

It is clear why this variant is met with suspicion by some language users. The comparative seems to be out of place here, followed as it is by the equative standard marker wie. We actually encounter examples where wie seems to have been 'corrected' into the comparative standard marker als (note that in non-standard German wie is often used instead of als after comparatives):

(14) a. Die vier Freundinnen sind unterschiedlicher als sie nicht sein The four friends are more.unlike than they not be könnten.

could

'The four friends are as unlike as they could be.'

[http://www.tinkerfairysbibliothek.wordpress.com/category/genre-serie]

b. Der Rest der Oper ist russischer als es nicht sein kann.

The rest of.the opera is more.Russian than it not be can

'The rest of the opera is as Russian as can be.'

[http://www.der-neue-merker.eu/paris-salle-pleyel-iolanta-mit-anna -netrebko-als-engel-des-lichts]

But interpreting the comparative form in situ as a comparative ('more unlike than they could not be' etc.) would result in gibberish. The construction is denotationally equivalent to an equative with a positive in the parameter position.

Surprisingly, the German case is not unique. Besides the Early Modern Dutch construction in (3) and the Early Modern West Frisian construction in (4), we find the Modern West Frisian construction in (15), where the comparative is in the parameter position (cf. Hoekstra 2012):

(15) a. Hjar man hie, better as ik net wit, skoalmaster to Mieregea west. Her husband had, better as I not know, schoolmaster in Mieregea been 'Her husband had been a schoolmaster in Mieregea, as far as I know.'

[J.S. v.d. Steegh, oant. 203 (1884)]

b. Better as ik net wit leit Hurdegaryp yn Fryslân.

Better as I not know lies Hurdegaryp in Fryslân

'As far as I know, Hurdegaryp lies in Fryslân.'

[B. v.d. Veen, L.C. 26-11-1962, p.5]

Although Frisian has the same standard marker as for equatives and comparatives, interpreting the comparative in place again results in nonsense. 
Finally, English provides a case where a superlative shows up in the parameter position. Next to the construction in (5) and (6), we have the one in (16):

(16) a. I have examined as best as I can the mental habits which are common to all forms of nationalism.

[http://www.orwell.ru/library/essays/nationalism/english/e_nat]

b. Obviously, the Pentagon is trying to manage the situation as best as they can.

[http://www.swampland.time.com/2013/04/30/barack-obamas-whitehouse-press-conference-april-30-2013-transcript]

c. I'll try to explain things as best as I know how.

[http://www.kurtzacres.wordpress.com/2013/04/16/feeding-bees-better]

The position of the superlative best in the context as...as is very odd; normally only positive adjectives or adverbs are found here (as big as, ${ }^{\star}$ as biggest as). But although conscious language users may have some qualms about this construction and might tend to choose an alternative, the construction is quite commonly used.

Summarizing, there seems to be a tendency in West Germanic languages in potentiality equatives for a comparative or a superlative to be realized in the parameter position.

\section{Analysis II}

The only literature on potentiality equatives that I know of (besides Hoekstra 2012) is a column by Nathan Bierma in the Chicago Tribune (11 January 2006) on as best (as) I can in English (also published in Bierma (2009: 15-17)). The construction as best (as) I can baffles both purists and linguists (Bierma asked linguists like Geoffrey Pullum and Mark Libermann for their opinion). Although it seems to be "technically wrong", it is widely accepted and "sometimes used by reputable speakers in formal situations". Moreover, Bierma quotes evidence provided by Liberman (2005) that the construction is pretty old, especially in the form as best I can/may. Compare:

(17) a. My formula for living is quite simple. I get up in the morning and I go to bed at night. In between, I occupy myself as best I can. (Cary Grant)

b. I have thrust my self into this maze / Haply to wive and thrive, as best I may. 
He concludes that all in all as best (as) I can cannot be "the worst grammatical slip faux pas".

I am not sure if Bierma and Liberman are right in putting as best I can on a par with as best as I can, at least historically. They probably assume that in the former the equative standard marker is dropped as in cases like I am running as fast (as) I can. However, considering the fact that as best I can is older than as best as I can, the superlative in as best I can might just as well be in a topicalized position inside the standard clause immediately following the standard marker as. This position of the superlative can be compared to that in expressions like as best is for thi soule (Piers Plowman, 14th century), as best is known (next to as is best known) or as best I see fit (next to as I best see fit). Perhaps it is possible to reconcile both analyses if we assume that as best I can with a standard marker as and topicalization of best has been reanalysed as as best (as) I can with a parameter marker as and a deleted standard marker as and could then develop into as best as I can with an overt standard marker:

(18) $\mathrm{as}_{\mathrm{SM}}\left[\right.$ best I can] $>\mathrm{as}_{\mathrm{PM}}$ best $\left(\mathrm{as}_{\mathrm{SM}}\right)[\mathrm{I}$ can $]>\mathrm{as}_{\mathrm{PM}}$ best as $\mathrm{SM}_{\mathrm{SM}}[\mathrm{I}$ can $]$

If such a reanalysis took place, although the result is "technically wrong", it shows again that something special must be going on in this type of constructions.

The semantics of potentiality equatives can be considered the condition sine qua non for realizing the adjective/adverb in these constructions as a comparative or a superlative. On the other hand, it must have been the desire to be expressive that prompted language users not only to use a more prominent form of the adjective/adverb (the comparative or the superlative instead of the positive), but also to put this form in a prominent position, i.e. to scramble it (as in German wie sie unterschiedlicher nicht sein könnten), to topicalize it (as perhaps in English as best I can) and even to illegitimately front it into the parameter position.

One might perhaps want to entertain the idea that the superlative in English or the comparative in German and Frisian actually moved from the standard clauseinternal position to the parameter position. But such movement is out of the question. If we analyse equative comparison as some sort of specifying coordination (cf. De Vries 2009), we would have movement from the second conjunct to a position in the first conjunct, which is unparallelled and which most syntactic theories justifiably rule out.

That the illegitimate positioning of a comparative or a superlative in the parameter position is still widely accepted is not only due to the specific semantics of these constructions and their expressive force, but also to their predominantly idiomatic nature. The constructions have a lexically fixed, non-compositional meaning, so they can, to some extent, cope with syntactically/compositionally aberrant forms and structures. ${ }^{7}$ 


\section{Conclusion}

In this article I discussed some properties of potentiality equatives, a construction type that had not previously been recognized as such in the literature. I argued that the variation in form and position of the adjective/adverb in potentiality equatives results from its semantics, from its expressive force and from its idiomatic nature. ${ }^{8}$

\section{Notes}

1. The present article extends a previous article of mine (Hoekstra 2012) in which I focused on the West Frisian data. An earlier version was presented at the Linguistic Colloquium of the Institut für Skandinavistik, Frisistik und Allgemeine Sprachwissenschaft of the University of Kiel (Germany) on 21 November 2013.

2. All the internet sources were accessed in December 2013.

3. One can find occasional examples with other potentiality predicates like möglich sein und gehen:

(i) a. Ihre anspruchsvollen Gäste werden verwöhnt, wie es besser nicht möglich ist. Your demanding guests are indulged, as it better not possible is [http://www.thiel-grosskuechenbedarf.de/pdf/geschirr-schoenwald.pdf]

'Your demanding guest are indulged as well as possible.'

b. Perfekt gebügelte Wäsche, wie es schneller nicht geht.

Perfectly ironed linen, as it quicker not goes

[http://www.markt.de/keywords,laura-star/suche]

'Perfectly ironed linen, as speedily as possible.'

4. The construction is found in Old Frisian as well:

(i) ...ende dyn schaed ... toe likyen elck alsma best mey (O II, 153, 33)

... and the damage to settle each as.one best may

'and to pay the damages, everyone as well as he can'.

5. Rett (2010, to appear) discusses so-called Measure Phrase Equatives in English which are special in that they only have an 'at most' interpretation:

(i) Temperatures ( ${ }^{\star}$ exactly) as high as $105^{\circ} \mathrm{F}$ have been recorded.

In (i) the measure phrase gives the maximum temperature (but lower temperatures have been recorded) and an 'exactly' interpretation is not possible.

6. The particle may not occur with the verb 'to know', perhaps because it is stative (e.g. Frisian sa goed as $i k^{*}($ mar $)$ wit 'as far as I know').

7. Also compare the variation in German in expressions like 'as A as possible': so schnell wie möglich, schnellstmöglich, möglichst schnell.

8. Another construction expressing potentiality is the modal to-infinitive. Interestingly, we find a construction niet beter(s) te weten 'as far as I know' (lit. not better to know) in Southern Dutch (Brabant, Flanders). A variant with apparent fronting of the comparative is found in Modern West Frisian better net te witten (for ample discussion see Hoekstra 2012). 


\section{References}

Bierma, Nathan. 2009. The eclectic encyclopedia of English. Sherwood, Oregon: William, James \& Co.

Bresnan, Joan. 1973. The syntax of the comparative clause construction in English. Linguistic Inquiry 4. 275-343.

Chomsky, Noam. 1977. On wh-movement. In Peter Culicover, Thomas Wasow \& Adrian Akmajian (eds.), Formal Syntax, 71-132. New York: Academic Press.

Foolen, Ad. 1993. De betekenis van partikels. Een dokumentatie van de stand van het onderzoek met bijzondere aandacht voor "maar". PhD dissertation, Nijmegen.

Haspelmath, Martin \& Oda Buchholz. 1998. Equative and similative constructions in the languages of Europe. In Johan van der Auwera (ed.), Adverbial Constructions in the Languages of Europe (Empirical Approaches to Language Typology/EUROTYP, 20-3), 277-334. Berlin: Mouton de Gruyter.

Henkelmann, Peter. 2006. Constructions of equative comparison. STUF - Language Typology and Universals 59. 370-398. DOI: 10.1524/stuf.2006.59.4.370

Hoeksema, Jack. 2003. In het minst: eigenschappen en ontwikkeling van een negatief-polaire uitdrukking en de neergang van focus scrambling. Tabu 33. 27-50.

Hoekstra, Jarich. 2012. Better net te witten - better as ik net wit. Us Wurk 61. 158-172.

Hoekstra, Jarich. To appear. "Sa kâld net as juster." Eat oer scrambling yn it Frysk. Us Wurk.

Van der Horst, Joop. 2008. Geschiedenis van de Nederlandse syntaxis. 2 Dl. Leuven: Universitaire pers Leuven.

Kennedy, Christopher. 1999. Projecting the adjective: The syntax and semantics of gradability and comparison. New York: Garland Press.

Libermann, Mark. 2005. Asbestos she can. [http://www. itre.cis.upenn.edu/ myl/languagelog/ archives/002733]

Rett, Jessica. 2010. Equatives, measure phrases and NPIs. In Maria Aloni, Harald Bastiaanse, Tikitu de Jager \& Katrin Schulz (eds.), Logic, Language and Meaning (Lecture Notes in Computer Science vol. 6042), 364-373. Berlin: Springer. DOI: 10.1007/978-3-642-14287-1_37

Rett, Jessica. To appear. Measure phrase equatives and scalar implicature. Journal of Semantics.

De Vries, Mark. 2009. Specifying coordination: An investigation into the syntax of dislocation, extraposition and parenthesis. In Cynthia R. Dreyer (ed.), Language and Linguistics: Emerging Trends, 37-98. New York: Nova.

\section{Author's address}

\section{Jarich Hoekstra}

Institut für Skandinavistik, Frisistik und Allgemeine Sprachwissenschaft

Abteilung für Frisistik

Christian-Albrechts-Universität

Christian-Albrechts-Platz 4

24118 Kiel, Germany

j.hoekstra@isfas.uni-kiel.de 